УДК 821.161.1(430).09:394.5(64)

\title{
ІДЕНТИЧНІСТЬ ПОСТМОДЕРНОЇ ЛЮДИНИ
}

\author{
Мадлен Едуардівна Шульгун \\ https://orcid.org/0000-0002-5167-2806 \\ madlenbrief@gmail.com \\ докторка філологічних наук, професорка кафедри теорії та історії світової літератури \\ імені професора В. І. Фесенко, \\ Київський національний лінгвістичний університет
}

\begin{abstract}
Анотація. У статті проаналізовано твори Патріка Модіано і Ольги Токарчук. Розглянуто співвідношення актуальні образні моделі, які описують сучасну людину і претендують на широкі узагальнення. 3'ясовано, травелог і роман-подорож розиінюються нами як пошукові зонди сучасної літератури.
\end{abstract}

Ключові слова: ідентичність; часопростір; переміщення; подорож; новела; роман.

Постановка проблеми. Потенціал найширших філософських і культурологічних узагальнень, закладених у художньому коді подорожі, підтверджується тим, що образи, символи i концепти мандрівників використовуються для характеристики радикальних змін картини світу i концепції людини. Це відображено не тільки безпосередньо у травелозі, а і у формі романуподорожі, драми-подорожі, у філософських та культурологічних наукових працях. Тобто код травелогу проявляє себе як всеохопний, він зближує художній i аналітичний дискурси та відбиває закономірності перехідного художнього мислення.

У 1990 - 2000-ні роки з'явилася низка наукових досліджень, в яких протиставляється модерне і постмодерне бачення світу, причому відмінності втілюються у образи-метафори саме різних типів мандрівників. Серед таких наукових праць особливо репрезентативними й показовими стали розвідки Зігмунта Баумана, Джеймса Кліффорда, К. Каплана, Е. Саїда. Міркуючи над зміною ідентичності постмодерної людини, Зігмунт Бауман у якості варіанту базової моделі «туриста» називає «фланера». Такий підхід суттєво звужує семантику знаку «фланер». Але, підкреслимо, що точками перетину постмодерного «туриста» і певного типу артистичної поведінки (яка склалася у другій половині ХІХ століття) мають бути, по-перше, схильність до мандрів, по-друге, відсутність глобальної цілі руху i, зрештою, акцент на естетичному, а не моральному (на відміну від паломника) орієнтирах. Саме такі семантичні наголоси робилися у визначен- нях «фланера», закріплених у словниках: «Фланер - фр. - той, що гуляє вулицями без мети й необхідності, без діла, гультіпака» [8, с. 563]. Цей орієнтир, що увиразнився у західноєвропейському мистецтві і поведінці певних шарів творчої спільноти другої половини XIX - початку XX століття і входив у коло інших артистичних моделей самоідентифікації [3], [5], [4], дійсно, отримав розвиток у сучасних творах, але його модифікації і наповнення виявилися більш складними й тонкими, ніж схема 3. Баумана [1].

Враховуючи особливості «національних версій» постмодернізму і загальних особливостей перехідного художнього мислення, швидкої динаміки зміни орієнтирів, ставимо собі за мету виокремити актуальні образні моделі, які описують сучасну людину і претендують на широкі узагальнення. При цьому травелог і романподорож розцінюються нами як пошукові зонди сучасної літератури. Перспективним видається побудова типології героїв саме на матеріалі травелогу і роману-подорожі, оскільки в цьому плані вони демонтують єдині вектори пошуку при різних жанрових настановах. Порівняння можливостей і досягнень цих форм може дати цікавий матеріал для узагальнень щодо динаміки метажанру.

Виклад основного матеріалу. Власне, яскраву характеристику саме такої творчої поведінки, що формує буттєву біографію митця, дав Шарль Бодлер в есе «Поет сучасного життя» (1863р.). Риси певного узагальненого типу авторепрезентації Шарль Бодлер узагальнив у образі французького художника К. Гіса, утаємничено- 
го під ініціалами К. Г. (що відповідає інтенції фланера лишатися непомітним і не впізнаним). Поет підкреслює складність, невловимість, але й універсальність типу блукальника-спостерігача, який насолоджується картинами сучасного життя, розчиняється у його плині, мандрує за натовпом. «Назвіть такого художника як хочете - спостерігачем, підглядальником, філософом, але, намагаючись знайти визначення, ви подаруєте його епітетом, не придатним для характеристики побратима, який втілює нетлінні або ж довговічні героїчні чи релігійні феномени. Інколи цей художник - поет, частіше близький романісту, моралісту, він літописець тієї вічності, що відображена у швидкоплинності. У кожній країні, на іï славу і втіху, народжувалися художники такого складу» [2, с. 291].

Шарль Бодлер виокремлює низку типологічних рис такої моделі, причому той факт, що в ній домінує саме творча інтенція, суттєво відрізняє іiі від бездіяльного пустого гуляки, від «дозвільного фланера» [2, с. 287]. Серед таких особливостей наступні: схильність до мандрів, зацікавлення саме сучасністю, одержимість пристрастю бачити, відчувати, художньо відтворювати, описувати нрави. Окрім того, такий митець намагається бути непомітним у натовпі, він - спостерігач, інкогніто, невидимка. «Він дивиться, як тече потік життя, величний і сяючий. Він милується вічною красою і вражаючою гармонією великих міст, гармонією, яка дивом збереглася серед галасливого хаосу людської свободи» [2, с. 288].

Бодлер увиразнює не тільки манеру артистичної поведінки, невидимка, інкогніто, ніким не пізнаний принц у натовпі, а й особливості творчого бачення. Це те, що за традицією формальної школи називають «очудненням», а сам поет кваліфікує як гостроту і неупередженість дитячого зору, що пізнає світ, або ж погляд людини, яка після хвороби повертається до життя i відчуває його яскравість надзвичайно гостро.

Проголошується і наявність високої мети. Відзначимо, що така інтенція і подальша іiі характеристика Бодлером співвідноситься із всеохопною модерною моделлю «паломника» у класифікації типів модерної і постмодерної ідентичності 3. Баумана. Французький поет створює такий портрет: «I от він ходить, поспішає, шукає. Що він шукає? Людина, яку я описав, обдарована живою уявою, це самітник, що без втоми мандрує величезною людською пустелею, він, безсумнівно, переслідує більш високу мету, ніж безтурботний фланер, більш значущу, ніж швидкоплинне задоволення від миттєвого враження. Він шукає щось таке, що ми дозволимо собі визначити як дух сучасності <..>, намагається виокремити у швидкоплинному елементи вічності» [2, с. 287]. Саме така настанова дозволяє творцю-фланеру вилучити з людського потоку найяскравіші фігури, що увиразнюють дух епохи. У К. Гіса, за думкою Бодлера, це воїни, денді, жінки напівсвіту, тобто, додамо, фігури, що відбивають перехідність. «Денді з'являються переважно у перехідні епохи, коли демократія ще не досягла справжньої могутності, а аристократія лише частково втратила шляхетність і грунт $<\ldots>$ Денді - останній зліт героїки на фоні загального занепаду» [2, с. 300].

Відрефлектована Шарлем Бодлером модель митця-фланера, який мандрує паризькими вулицями (чи іншими містами), намагаючись відгадати таємниці людей, вловити містичний дух столиці й розгадати знаковий іï код, знайшла свій розвиток у творах відомого сучасного французького письменника Патріка Модіано, який у 2014 році став лауреатом Нобелівської премії.

Вказана модель героя реалізувалася у низці романів, в яких «дух сучасності» тісно пов'язаний із історичною пам'яттю, а конкретні локуси міста набувають символічних значень, мандри героя складають основну сюжетну лінію. Серед таких творів «Лише б не загубитися серед вулиць», «Вулиця темних лавок», «Одного разу в ночі».

Системотворчим стрижнем останнього роману стає саме блукання молодого героя Парижем i частково (у споминах та по мішленівській мапі) передмістями столиці. Саме це дає підставу критикам (Л. Зіміній, Д. Володарському) назвати Париж справжнім героєм твору. Місто ховає свої «таємниці», але інколи їх розкриває, повертає на коло блукання захопленого його загадками, красою, містичним духом поетично налаштованого фланера.

Найважливішими у житті героя стають саме мандри містом і вживання в дух конкретних районів. Усе інше, фактично, не описано, відсутні характеристики роботи, професії, зв'язок iз родиною розірваний, а пам'ять про минуле розмита незрозуміло чому: чи то через аварію, чи через духовну й емоційну амнезію самітника. 
Конкретика у змалюванні цих сфер з'являється лише у зв'язку із певними локусами міста: це райони і кафе, в яких проходили зустрічі з мовчазним i утаємниченим батьком. Це орендовані кімнати, колись покинуті і згадувані під час кружлянь. Назви передмість пробуджують непевні спогади про дитинство, а запах повітря однієї з вулиць повертає у часи загубленого кохання.

Мандри набувають екзистенціального виміру, герой намагається зібрати до купи спогади і враження, розгадати «знаки» міста, щоб змоделювати власну цілісність. Одночасно блукання зберігають самодостатність пригод і продовжують традицію розслідування «паризьких таємниць».

Подібна налаштованість героя підсилюється подією, що має стати спусковим механізмом нових мандрів, спостережень Парижу, його людських типів. Це інцидент автомобільної аварії, яку вчинила загадкова жінка. Вона виступає у ролі винуватиці (ранить героя), доброзичливого янгола (начебто, сплачує лікування й лишає велику суму грошей, що дає можливість фланеру і в подальшому безтурботно мандрувати), головної таємниці Парижу, адже незнайомка зникає. Бажання її знайти підштовхує до постійного пошуку й розгадок детективних та топонімічних кросвордів міста. Отже ситуація пошуку накладається на неспокійний характер фланера, тяжіння до мандрів подвоюється. «Потрібен був шок, щоб вирвати мене з летаргії. Я просто не міг більше блукати в тумані невизначеності $<\ldots>$ Без сумніву, ця аварія - одна 3 вирішальних подій в моєму житті. Повернення до нормального ходу речей» [7, с. 38].

Зробимо спробу виокремити в образі героя “Одного разу в ночі" традиційні риси митця-фланера і увиразнити вектори модифікації моделі.

Сам герой характеризує себе як «бродягу» [7, с. 39], принаймні впевнений, що саме таке враження справляє на оточуючих у своєму старому одязі та і з закривавленою пов'язкою на нозі. Оточуючим мета блукань героя невідома, i на початку вона не досить ясно зрозуміла й самому хлопцеві.

Але поступово він розуміс, що невпинні мандри Парижем мають метафізичний характер. Підкреслюється особливий ірраціональний зв'язок між цим блукачем і міським простором.
I цей зв'язок є сильнішим та якісно іншим, ніж у традиційного фланера. Певні місця, будинки, кафе, цікавини маршруту набувають значення таємних знаків, підказок, увиразнюються «реперні точки» на реальній та уявній мапах, які можуть бути дороговказами до розгадки таємниць людських доль. «Типографія, без сумніву, мала для мене занадто велике значення. Я часто питав себе, чому протягом кількох років місця, де ми зустрічалися з батьком, поступово зміщувалися з Єлисейських полів до Орлеанських воріт? Я навіть повісив на стіні моєї кімнати на вулиці Вуа-Верт план Парижу. Ручкою відмічав реперні точки. <..> чи не 3'явилася раптом у кочовому житті мого батька якась константа?» [7, с. 18].

Таємничий модус загострюється ще й тим, що більшість мандрів герой здійснює надвечір або вночі, тому що це підсилює враження, надає їм містичного відтінку, очуднює і змінює систему координат сприйняття, а це співвідноситься iз тим жадібним «дитячим» поглядом на світ, який, за думкою Шарля Бодлера, притаманний саме митцеві-фланеру. Деякі локуси, наприклад, Площа Пірамід, завжди манять, притягають, дають ірраціональне відчуття щастя і стають локусами, які «перемикають» життя героя 3 регістру летаргії до регістру пошуків і збирання себе. Такий простір в уяві «бродяги» окреслений кордоном (це квартали лівого і правого берегів Сени, залучення образу ріки відразу підключає міфологічні підтексти великої дороги і переходу між світами).

Топоніми Парижу стають знаками універсальної картини світу із увиразненням раю, пекла, місць сили, переходів, зрештою, концентричних кіл блукання й доцентрових маршрутів, які мають привести героя до розуміння найважливіших таємниць.

Квартали лівого берега асоціюються із позитивним, райським полюсом світу. Вони наче «наелектризовані» навіть в ночі, коли вікна темні. Традиційну символіку раю втілюють і парки «на французький манер», до яких герой відчуває особливу симпатію і вважає, що такий вибір пріоритетів характеризує його як людину, що націлена на щастя. У подібному ж ключі виконано опис Орлеанських воріт. Саме тут знаходяться найулюбленіші знаки міста, його прикмети і цікавини, що у свідомості героя набувають містичної сили, значення «місць сили», 
захисту і дороговказу. «Влітку на фоні листя особливо виразно виглядав великий бронзовий лев, і кожного разу, коли я дивився удалину, його присутність на горизонті надавала мені душевного спокою. Мені здавалося, що він охороняв моє минуле. І майбутнє також. Цієї ночі він став для мене опорою. Такому вартовому неможливо не довіряти» [7, с. 31]. Міфологічні асоціації і тут значно розшифрують семантику сцени блукання, оскільки лев у багатьох культурах, що відображено у живописі і архітектурі, виступає як містичний страж сакрального місця (храму, гробниці, воріт) і одночасно символ певної сторони світу $[6$, с. 41$]$. В романі цей знак стоїть як дороговказ і символ переходу (як і річка) в інший простір, світ, розуміння себе. У деталях пейзажу герой налаштований бачити таємні знаки, що напряму асоціюються із євангельським спасінням - «мені послано благу звістку» [7, c. 35].

Але $\epsilon$ квартали, які асоціюються із пеклом, або зникненням, тобто утворюють протилежний, контрастний полюс картини світу. Вони лякають, створюють враження пустоти, породжують майже інфернальні страхи. Наприклад, прогулянка наодинці повз покинуті будинки Військової академії завершується панікою, відчуттям лабіринту, з якого не вибратися, загрози розчинитися у зимовому сніжному тумані. Деякі локуси породжують відчуття пустоти й повертають до споминів про втрати, моделюють трагічне бачення власної долі. До таких належить відрізок метро між Данфер і площею Італії, коли потяг відривається від землі і прямує мостами над бульварами й будівлями. У цьому вбачається асоціація із польотом та митарствами душі після смерті, тобто, знову актуалізуються міфологічні підтексти, кодовані знаками міського простору i блуканнями «фланера». У поверненні в підземний тунель герой вбачає запоруку відновлення звичайного, повсякденного життя, монотонності буднів, схожої на повторюваність станцій.

Так само міфологічних підтекстів набуває композиція мандрів. Постійні повтори, повернення, блукання манівцями, враження дежавю, мотиви «вічного повернення», неможливість згадати, зрозуміти суть локусу і його значення в минулому і долі в цілому, - це традиційні форми художнього втілення інфернального кола. А доцентровий рух до мети - реалізація сакрального паломницького орієнтиру. Такими центра- ми стають місця екзистенціального прозріння, $\mathrm{i}$ вони характеризуються героєм із майже релігійним пафосом. «Усі мої переміщення навкруги Парижу, усі маршрути мого дитинства, переїзди $з$ лівого берега Сени у Венсенський і Булонський ліси, з півдня на північ, зустрічі з батьком, мої власні блукання в останні роки - усе привело мене у цей квартал на схили пагорбу на березі Сени. <..> мені послано благу звістку <..> нехай я отримав це послання тільки нещодавно, не все ще втрачено» [7, с. 35].

Містичний настрій твору і його міфологічні підтексти підживлює й система символів. Усі вони пов'язані із характером реального і уявного руху в просторі й часі. Це й чорний собака, що матеріалізувався з дитячих спогадів і вказав блукальцю доцентрову дорогу до того самого місця, де його має охопити осяяння й змінитися доля. Це й контрастний символ божевільної старої, яка, здається, теж якось пов'язана із минулим, але втілює небезпеку зупинки на місці. Вони з'являються на перехрестях, у кордонів (вулиць, будинків), а потім зникають у воронці часу. Усі знаки інтерпретуються містично й екзістенціально: «Я знайшов знак-дороговказ. Це як голка, загублена у скирті сіна, або, якщо пощастить, та нитка, завдяки якій можна буде поновити рух часу» [7, с. 34].

У системі увиразнюються традиційні символи перехідного художнього мислення. Це, перш за все, корабель, але у специфічних смислових модифікаціях. Герой відчуває себе пасажиром лайнера, який опинився у відкритому морі, але залишається нерухомим, виникають асоціації 3 полоном. Іншим пасажиром - хитрим, який не платить за проїзд, - уявляється батько із його шахрайськими замашками i самозванством. Варіацією корабля стає і «Фіат», що збив героя, тим більше, що він має символічний колір морської хвилі, а в екзистенціальному плані переносить «блукальця» 3 нижчого плану самоусвідомлення («летаргії», сну, невиразності) до вищого. «<...> інколи я запитував себе, чи мають сенс мої пошуки, чому вони так мене захопили? $<\ldots>$ раніше <..> у мене було таке відчуття, що виник нізвідки. <..> Зараз <..> я запитував себе, чи зможу я, незважаючи на незнання власного коріння і невиразне уявлення про дитинство, відшукати точку опори, щось варте довіри - те, що допомогло б мені стати на ноги? Може, $є$ цілий прихований від мене шматок мого 
життя, здатний стати твердою землею серед хитких пісків? I мені чомусь здавалося, що “фіат” кольору морської хвилі і та, що була за кермом, допоможуть мені відкрити його» [7, с. 42].

Звертаємо увагу на показові асоціації, які виникають у загальному дискурсі подорожі: це зв'язок між великими географічними відкриттями далеких земель, що здійснювалися мореплавцями на кораблях, важким шляхом прочан крізь пустелю і екзистенціальним пошуком особистістю себе, власної цілісності.

Наступною типологічною рисою митця-фланера, за Шарлем Бодлером, $є$ його схильність до спостереження за натовпом з позицій невидимки, виокремлення тих типів, що втілюють «дух епохи». Саме ці риси культивує у собі герой роману Модіано. Його девізом стає «Будьте спокійні й мовчазні, розчиняйтеся в оточуючому світі» [7, с. 35]. Він спостерігає за життям Парижу через вікна кафе, заглядає у вікна будівель, пристає до груп людей (наприклад, слухачів і адептів «доктора» Був'єра), радіє, що ніхто не звертає на нього увагу, йде слідом за тими людьми, що його зацікавили.

Окрім «фланера» орієнтиром у такій творчій поведінці стає сучасник Шарля Бодлера письменник Ежен Сю, автор роману «Паризькі таємниці». Коментуючи свої розвідки й слідування шляхами певних людей, герой підкреслює: «Тоді мене по-справжньому дуже хвилювало те, що називають “паризькими таємницями”» [7, с. 16]. I в цьому випадку митця-фланера цікавить те, як змінюється людина, потрапляючи у різні райони Парижу, тобто, як локуси впливають на самовідчуття, зміну ролей, автопрезентацію. Це він намагається відстежити, зокрема, на прикладі поведінки батька і «доктора» Був'єра.

Показовим $є$ й коло типажів, яких виокремлює і художньо «досліджує» герой роману. Воно певними точками співпадає із набором моделей тих, хто, за Бодлером, увиразнює «дух епохи», зокрема, це фатальні жінки і жінки напівсвіту. Але із актуального переліку вилучені «денді», «військовий», а залучені різного плану шахраї і самозванці (а останнє характеризує саме перехідне мислення). До таких належить батько героя, який займається темними справами, удає 3 себе авторитетну фігуру. Варіацією моделі є «доктор» Був'єр, він претендує вже не тільки на чужі гроші, а й на душі. Самозванець створює свою чи то релігію, чи то вчення із вульгаризо- ваних фрагментів різних психологічних теорій і релігій, грає роль гуру та експлуатує адептів. Більш загадковою стає фігура «неангела» - ділка Моравські, що живе під псевдонімами, тобто, знов-таки, грає ролі, наближається до самозванства. Всі ці люди, за визначенням героя, «авантюристи», «шахраї, кожний на свій манер», «кочівники». Висунення таких фігур на перший план, що характеризують сучасність, увиразнює критичне ставлення автора до стану культури, рефлексію кризи й перехідності.

Показово, що герой не піддається чарам жодного із шахраїв. Сам він це пояснює іронічно власною безтурботністю та лінивою вдачею, яка не дає можливості захопитися і потрапити у пастку. Але активні пошуки нівелюють таку характеристику, проявляючи інше - «фланерську» філософську відстороненість і художній хист виокремлювати основне й типове у людській особистості, тобто прозорливість митця. Яскраво виступає поєднання рис різних моделей: фланера, митця, екзистенціальної людини, що пережила шок, відмовилася «блукати у тумані невизначеності», забажала «змінити хід <..> життя» [7, с. 34].

Певні риси «фланера» має і героїня твору Ольги Токарчук «Бігуни». Але ознаки такого типу блукальця вписуються у більш складну модель, що, на наш погляд, свідчить про часткове засвоєння такої традиції сучасним польським травелогом, увиразнює синтез із іншими, домінантними орієнтирами, притаманними національному мистецтву слова, зокрема, 3 моделлю мандрівного філософа, прочанина (чи «антипрочанина», що рівною мірою актуалізує філософський і релігійний дискурс).

Серед рис «фланера», що проявилися у складному синтетичному характері героїні-оповідача, називаємо наступні. Це не просто жага до постійного руху, а й бажання спостерігати за людьми, лишаючись неполіченою. Так чинить і сама героїня, і інші персонажі історій. Вони вдають із себе людей-невидимок. Цьому сприяє те, що за інших обставин та в інакшій системі координат було б оцінено як недолік чи нещастя. Оповідачка і деякі героїні знаходять переваги в тому, що вони - жінки середнього віку й не дуже привабливі. Саме це робить їх ніякими, непомітними й відкриває можливості спостерігати за іншими, втручатися в долі, створює «алібі» у доволі сумнівних ситуаціях. Мотив «невиди- 
мості» виходить за межі традицій «фланерства» i характеризує певні сторони картини світу. Зокрема, волею уяви, невидимими чи неіснуючими, віртуальними стають ті локуси, де героїню спіткала невдача, вони сприймаються як травма й стираються із внутрішньої «мапи» свого світу, а люди, що їх населяють, набувають рис привидів. Невидимою є внутрішня, незбагнена сутність світу, яка лише інколи проривається назовні чимось або прекрасним, або ж жахливим, тобто не буденним. Власне, метою подорожей стає пошук таких проривів справжньої реальності, тобто з'являється філософське надзавдання, не обов'язкове у моделі «фланера» і неможливе в моделі постмодерного «туриста». Це вже атрибут мандрівного філософа.

Тим не менш, свою «невидимість» героїня використовує, як і фланер, для спостереження й вживання у образи людей, які iï зацікавили. Вона йде за ними, переслідує, вдивляється, а потім включає творчу уяву й дописує колізії їх життя, трагедії, конфлікти, можливі виходи із лабіринтів долі.

Героїня «Бігунів», на наш погляд, подібно до фланера, намагається вловити «дух сучасності», втілений у репрезентативних фігурах. Виокремлення кола таких «типів епохи» може слугувати розкриттю авторської концепції сучасного світу й людини. На наш погляд, домінантним «типом епохи» автор «Бігунів» вважає саме блукальця у

\section{СПИСОК ВИКОРИСТАНИХ ДЖЕРЕЛ}

1. Бауман 3. От паломника к туристу [электронный peсурс] / 3. Бауман // Социологический журнал. - 1995. - №4. - С. 133-154.

2. Бодлер Ш. Поэт современной жизни // Шарль Бодлер об искусстве Пер. с фр. Н. И. Столяровой и Л. Д. Липман. - М. : Искусство, 1986. - C. 283-315.

3. Kreuzer H. Die Boheme. Beiträge zu ihrer Beschreibung. Stuttgart, 1968.

4. Кривцун О. А. Психология искусства. - М. : Издательство Литературного института им. А. М. Горького, 2000. - 224 с.

5. Кривцун О. А. Художник и артистический мир // Человек. - 1993. - №2. - С. 22-28.

\section{REFERENCES}

1. Bauman Z. Ot palomnyka k turystu [эlektronnыi resurs] / Z. Bauman // Sotsyolohycheskyi zhurnal. 1995. - №4. - S. 133-154. різних його іпостасях: шукача пригод, туриста, представника певної субкультури, мандрівника шляхами історії й культури, екзистенціальної людини, яка моделює свій життєвий шлях пізнання себе й світу без жодних гарантій досягти успіху. Типами епохи обираються близькі автору пасіонарні, рухливі фігури, причому не тільки сучасні, а ті, що у попередні періоди формували зразки й традиції опору інерції й несправедливості життя. Тобто естетична складова світобачення «фланера» витісняється ідейним навантаженням, пасіонарною енергією, які притаманні польському й українському травелогу 2000-х в принципі.

Висновки. Таким чином, модель «фланера» актуалізована у сучасному романі й травелозі. Вона зберігає свої традиції (вироблені літературою ХІХ століття), виходить за межі її сучасних постмодерних інтерпретацій. Зберігаються iii основні складові: увиразнення певного типу митця - блукальця, урбаніста, споглядальника, невидимки, який намагається вловити «дух сучасності» і змалювати образи знакових фігур, які цей дух епохи втілюють. Проявленість моделі неоднакова у різних національних літератуpax В конкретних випадках вона поєднується iз іншими традиціями (мандрівного філософа), формуючи синтетичну модель митця і набуваючи невластивих їй від початку рис пасіонарності й ідеологичності.

6. Мифы народов мира. Энциклопедия: в 2 т. Т. 2: К - Я / Гл. ред. С. А. Токарев. - изд. 2-е. - М.: Советская энциклопедия, 1992. - 719 с.

7. Модиано П. Однажды ночью / Пер. с фр.: Зимина Людмила. - М. : Текст, 2015. - 160 с.

8. Полный и иллюстрированный словарь иностранных слов с указанием их происхождения, ударения и научного значения. 212 рисунков в тексте. Составил И. Вайсвлит. - М. :, Л. : Кооперативное издательство, 1926. -680 с.

9. Токарчук О. Бігуни: роман / О. Токарчук: пер. 3 пол. О. Т. Сливинського, худож-оформлювач О. М. Артеменко. - Харків: Фоліо, 2011. - 414 с. - (Карта світу).

2. Bodler Sh. Poэt sovremennoi zhyzny // Sharl Bodler ob yskusstve Per. s fr. N. Y. Stoliarovoi y L. D. Lypman. - M. : Yskusstvo, 1986. - S. 283-315. 
3. Kreuzer H. Die Boheme. Beiträge zu ihrer Beschreibung. Stuttgart, 1968.

4. Kryvtsun O. A. Psykholohyia yskusstva. - M. Yzdatelstvo Lyteraturnoho ynstytuta ym. A. M. Horkoho, 2000. - 224 s.

5. Kryvtsun O. A. Khudozhnyk y artystycheskyi myr // Chelovek. - 1993. - №2. - S. 22-28.

6. Myfy narodov myra. Эntsyklopedyia: v 2 t. T. 2: K - Ya / Hl. red. S. A. Tokarev. - yzd. 2-e. - M.: Sovetskaia эntsyklopedyia, 1992. $-719 \mathrm{~s}$.
7. Modyano P. Odnazhdy nochiu / Per. s fr.: Zymyna Liudmyla. - M. : Tekst, 2015. - $160 \mathrm{~s}$.

8. Polnyi y ylliustryrovannyi slovar ynostrannykh slov $\mathrm{s}$ ukazanyem ykh proyskhozhdenyia, udarenyia y nauchnoho znachenyia. 212 rysunkov $v$ tekste. Sostavyl Y. Vaisvlyt. - M. :, L. : Kooperatyvnoe yzdatelstvo, 1926. - $680 \mathrm{~s}$.

9. Tokarchuk O. Bihuny: roman / O. Tokarchuk: per. Z pol. O. T. Slyvynskoho, khudozh-oformliuvach O. M. Artemenko. - Kharkiv: Folio, 2011. - 414 s. (Karta svitu).

\title{
IDENTITY OF POSTMODERN MAN
}

\author{
Madlen Shulhun \\ https://orcid.org/0000-0002-5167-2806 \\ madlenbrief@gmail.com \\ Doctor of Sciences (Philology), Professor, Department of Theory and History of \\ World Literature named after Professor V.I. Fesenko, Kyiv National Linguistic University
}

\begin{abstract}
The article examines works by Patrick Modiano and Olha Tokarchuk with a focus on correlation of actual literary models describing modern man and claiming broad generalizations. Travelogue and journey novel have been considered as 'exploratory probes' of modern literature.
\end{abstract}

Key words: identity; time and space continuum, relocations; travelogue; journey novel; roman. 